\title{
New data on the Paleogene lithostratigraphic units' distribution in the Avren Step south of Varna and Beloslav Lakes based on borehole data and seismic profiles' interpretation
}

\author{
Boris Valchev, Hristo Dimitrov \\ University of Mining and Geology "St. Ivan Rilski”, 1700 Sofia, Bulgaria; \\ E-mails: b_valchev@mgu.bg, hristo_dimitrov@mgu.bg
}

\section{Нови данни за разпространението на палеогенските литостратиграфски единици в Авренското стъпало, южно от Варненското и Белославското езеро, на базата на сондажни данни и интерпретация на сеизмични профили}

\author{
Борис Вълчев, Христо Димитров \\ Минно-геоложки университет „Св. Иван Рилски“, София 1700
}

\begin{abstract}
Резюме. Настоящата статия има за цел да представи нови данни за пространственото разпространение и литоложките особености на палеогенските литостратиграфски единици в Авренското стъпало, което е част от Мизийската платформа в Източна България. Въз основа на първична литоложка информация от 81 сондажа, както и литостратиграфска интерпретация на пет сеизмични профила, са разпознати шест официални палеогенски литостратиграфски единици: Комаревска (Танет), Белославска (Ипрес), Дикилиташка (Ипрес), Аладънска (Ипрес), Авренска (най-горен Ипрес-Приабон) и Русларска свита (Олигоцен). Пространственото разпространение и техните взаимоотношения са визуализирани чрез построяването на пет геоложки разреза, засягащи северната част на изследвания район, а дълбочинният строеж на южната част е показан чрез петте сеизмични профила. Четири от единиците (Белославската, Дикилиташката, Аладънската и Русларската свита) показват постоянство в литоложките си характеристики и неголеми промени в дебелината. Комаревската, и особено Авренската свита, се характеризира със значителни вариации в литоложкия състав и дебелината.
\end{abstract}

Ключови думи: Палеоген, литостратиграфия, сондажни разрези, сеизмични профили, геоложки разрези, Авренско стьпало.

\begin{abstract}
The present article aims to provide new data on the spatial distribution and lithological features of the Paleogene lithostratigraphic units in the Avren Step, which is a part of the Moesian Platform in Eastern Bulgaria. On the basis of primary lithological data derived from 81 boreholes' sections and lithostratigraphic interpretation of five seismic profiles, six formal Paleogene lithostratigraphic units were recognized. They are as follows: the Komarevo Fm. (Thanetian), the Beloslav Fm. (Ypresian), the Dikilitash Fm. (Ypresian), the Aladan Fm. (Ypresian), the Avren Fm. (uppermost Ypresian-Priabonian), and the Ruslar Fm. (Oligocene). Their spatial distribution and relationships in the northern part of the studied area are visualized by drawing up of five geological cross-sections, while the deep geological structure of the southern part is shown by lithostratigraphic interpretation of the five seismic profiles. Four of the units (the Beloslav, Dikilitash, Aladan and Ruslar Formations) demonstrate almost constant lithology throughout the whole studied area with some variations in their thickness. The Komarevo Formation, and especially the Avren Formation, show considerable lithologic and thickness variability.
\end{abstract}

Keywords: Paleogene, lithostratigraphy, borehole sections, seismic profiles, geological cross-sections, Avren Step.

\section{Introduction}

In terms of the regional tectonic zonation, the Avren Step is a part of the eastern slope of the North Bulgarian Dome (sensu Georgiev, 2012), which is also known as Varna Monocline (Bokov et al., 1987), belonging to the Moesian Platform (Fig. 1a). The studied area comprises almost entirely the Avren
Plateau (excluding its western edge) and the southern part of the Varna Valley south of Varna and Beloslav Lakes (Fig. 1b). The Paleogene sedimentary rocks crop out only in the north-westernmost part of the plateau in the area of the town of Beloslav (Fig. 2) while in the other parts they are covered by Neogene sediments with various thickness. Therefore, the aims of this study are: (i) to recognize 

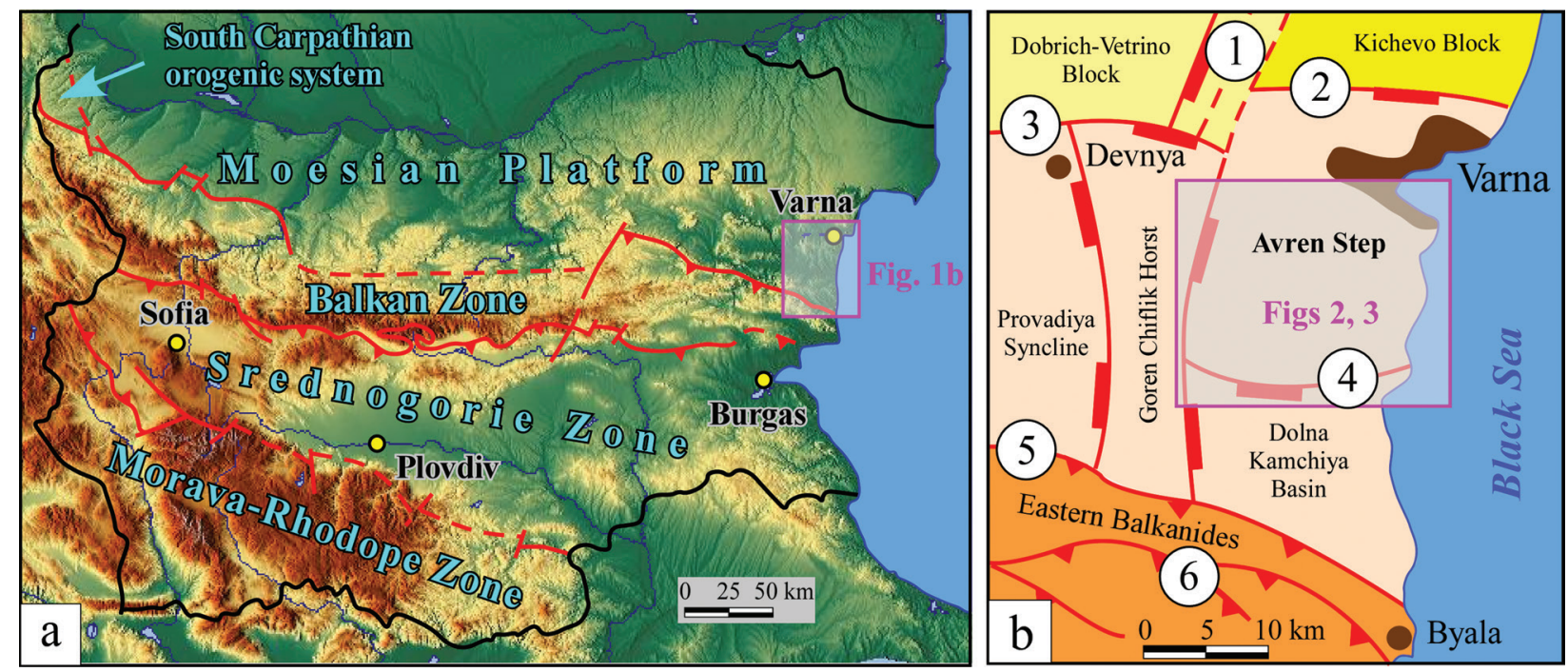

Fig. 1. a) Tectonic subdivision of the territory of Bulgaria (after Dabovski, Zagorchev, 2009) with location of the studied area; b) Tectonic subdivision of the onshore part of the Moesian Platform in Northeast Bulgaria (after Bokov et al., 1987) with location of the Avren Step

Faults: 1, Venelin-Dobrich zone; 2, Kichevo; 3, Resen-Medovina; 4, Bliznatsi; 5, Preslav-Shkorpilovtsi zone; 6, East Balkans frontal thrust

Fig. 1. a) Тектонска подялба на територията на България (по Dabovski, Zagorchev, 2009) с разположението на изследвания район; b) Тектонска подялба на сухоземната част на Мизийската платформа в Североизточна България (по Bokov et al., 1987) с разположението на Авренското стьпало

Разломи: 1 - Венелинско-Добричка зона; 2 - Кичевски; 3 - Ресенско-Медовински; 4 - Близнашки; 5 - Преславско-Шкорпиловска зона; 6 - Източнобалкански челен навлак

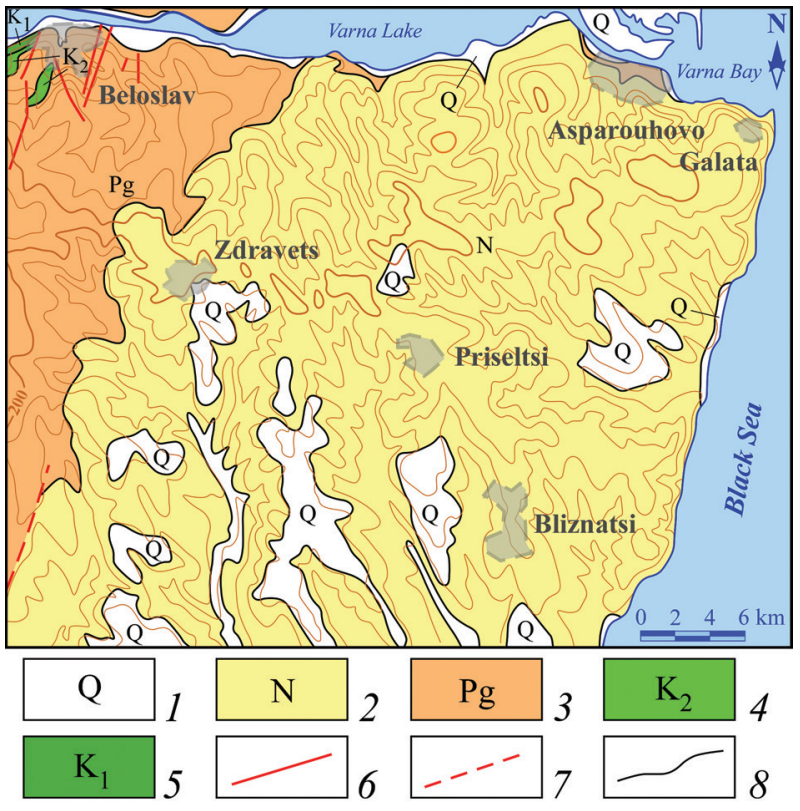

the exact lithostratigraphic succession by interpretation of borehole lithological logs and seismic profiles, (ii) to add new data concerning the lithological features, (iii) to illustrate the spatial distribution and relationships of the Paleogene lithostratigraphic
Fig. 2. Simplified geological map of the Avren Step and adjacent areas (after Cheshitev et al., 1991 with modifications) 1, Quaternary; 2, Neogene; 3, Paleogene; 4, Upper Cretaceous; 5 , Lower Cretaceous; 6 , proven fault; 7 , supposed fault; 8 , lithostratigraphic boundary

Фиг. 2. Опростена геоложка карта на Авренското стъпало и съседните райони (по Cheshitev et al., 1991, с изменения)

1 - Кватернер; 2 - Неоген; 3 - Палеоген; 4 - Горна Креда; 5 - Долна Креда; 6 - установен разлом; 7 - предполагаем разлом; 8 - литостратиграфска граница

units by drawing up of geological cross-sections, and thus (iv) to clarify the deep geologic structure of this part of the country.

\section{Studied material}

The present investigation is based on integration of the primary lithological data from 81 onshore borehole sections and five migrated 2D seismic profiles (the geological reports are kept at the National Geological Fund, Ministry of Energy of the Republic of Bulgaria), which are unevenly distributed across the studied area (Fig. 3). The boreholes were drilled and 


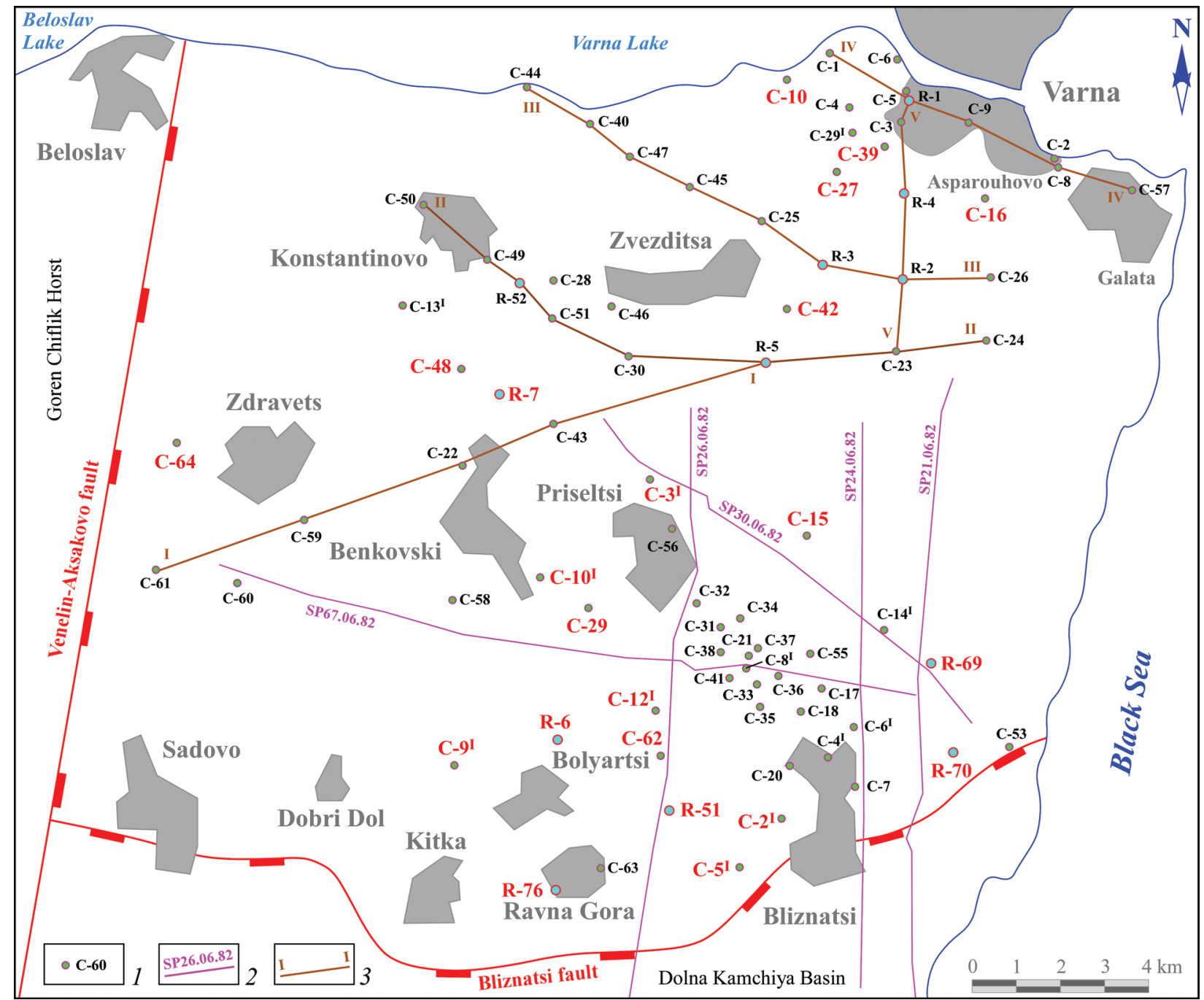

Fig. 3. Sketch map of the study area with location of the boreholes (1), seismic profiles (2), and geological cross-sections (3) The lithological logs of boreholes, marked in red, are shown in Figs 4 and 5

Фиг. 3. Схематична карта на изследвания район с разположението на сондажите (1), сеизмичните профили (2) и геоложките разрези (3)

Литоложките колонки на сондажите, маркирани в червено, са показани на фигури 4 и 5

studied from the early 1950 s to the early 1980 s, for oil and gas prospecting, and concern the following areas: Asparouhovo (Petuhov et al., 1952f'; Dacheva, 1962f $\mathrm{f}^{2}$; Kulev et al., 1965f $\mathrm{f}^{3}$, Konstantinovo

\footnotetext{
${ }^{1}$ Petuhov, S., A. Palij, L. Melnik. 1952f. Results of the Oil and Gas Prospecting in Northeast Bulgaria, based on Geological Investigations conducted in 1949-1951. Ministry of Energy, National Geological Fund, report III-97, 763 p. (in Russian, unpublished).

2 Dacheva, Z. 1962f. Report on the Results of the Borehole Investigations, conducted in 1954-1957 in Momino Plate and Varna Depression. Ministry of Energy, National Geological Fund, report III137, 401 p. (in Bulgarian, unpublished).

${ }^{3}$ Kulev, N., M. Nikolova, K. Bogdanova. 1965f. Report on the Results of the Deep and Structural Drilling in the Avren Plateau in 1961-1963. Ministry of Energy, National Geological Fund, report III162, 246 p. (in Bulgarian, unpublished).
}

(Petuhov et al., 1952f; Dacheva, 1962f; Kulev et al., 1965f), Zvezditsa (Dacheva, 1962f), Zdravets (Kulev et al., 1965f), Priseltsi (Petuhov et al., 1952f; Dacheva, 1962f;), Bliznatsi (Petuhov et al., 1952f; Kulev et al., 1965f; Nikolova, 1983f $\mathrm{f}^{4}$, and Ravna Gora (Petuhov et al., 1952f; Nikolova, 1985f $\mathrm{f}^{5}$ ). For the lithostratigraphic interpretation of the seismic profiles, we analysed seismic-sequence boundar-

${ }^{4}$ Nikolova, M. 1983f. Report on the Results of the Profile Drilling in Bliznatsi Area in 1981-1982. Ministry of Energy, National Geological Fund, report III-342, 328 p. (in Bulgarian, unpublished).

${ }^{5}$ Nikolova, M. 1985f. Report on the Results of the Exploration Drilling in Ravna Gora Area (R-76 Borehole). Ministry of Energy, National Geological Fund, report III-339, 138 p. (in Bulgarian, unpublished). 
ies and maximum flooding surfaces and correlated them to the interpreted here borehole logs that cross the profiles.

\section{Lithostratigraphic units}

On the base of the primary lithological data from the geological reports, we identified six formal lithostratigraphic units in the Paleogene succession of the studied region, which are as follows: the Komarevo, Beloslav, Dikilitash, Aladan, Avren, and Ruslar Formations. Some of the units demonstrate varieties in their lithological features, spatial distributions and relationships throughout the studied area. Valchev et al. $(2018,2019)$ discussed the nomenclature, definition, and stratigraphic background of the units. A brief description, concerning the lithological features, thickness and stratigraphic relationships of each unit in the Avren Step, is given below.

\section{The Komarevo Formation (Datchev, 1975)}

The unit is composed of pale-gray thin-bedded sandy or clayey-sandy micrite limestones, containing a large amount of glauconite and quartz grains in the lower levels. Mica flakes and chert nodules are locally common. Sandstone lenses at separate levels were also recorded. A single section in Asparouhovo area (R-4 Asparouhovo borehole) reveals the presence of a thin $(<1 \mathrm{~m})$ limy phosphorite layer in the uppermost levels, while another log (R-7 Konstantinovo borehole) includes a light gray sandstone package (17 $\mathrm{m}$ thick) with glauconite grains and rare chert nodules. The limestones contain nummulitids, small foraminifera, calcareous nannofossils, as well as organogenic detritus composed of bivalves, brachiopods, echinoids and crinoids (occurring commonly in the lower levels of the unit). The chronostratigraphic range of the Komarevo Formation in the Avren Step is determined as Thanetian on the base of molluscan fauna (Belmoustakov, 1962), nummulitids (Aladjova-Khrischeva, 1984; Aladžova-Hrisčeva, 1990), calcareous nannoplankton (Stoykova, Vangelov, 1997), and planktonic foraminifera (Juranov, unpublished data). The unit covers predominantly Upper Cretaceous rocks (usually the Mezdra Formation, introduced by Yolkichev, 1986), and rarely Lower Cretaceous levels (recorded in R-1 Asparouhovo, R-7 Konstantinovo, and R-51 Ravna Gora boreholes), as the boundary is an unconformity. The upper boundary is a sharp lithologic contact with the Beloslav Formation or an unconformity with the Dikilitash Formation. The thickness of the formation varies from $10 \mathrm{~m}$ (R-5
Zvezdtitsa borehole) to $102 \mathrm{~m}$ (R-7 Konstantinovo borehole).

The Beloslav Formation (Gočev, 1933)

It consists largely of pale-gray to gray-greenish, fine- to medium-grained loose sandstones to sands, composed almost entirely of quartz grains. In single sections the sandstones are interbedded with nummulitic limestones (C-59 Zdravets borehole) or they pass into siltstones with limy-clayey cement (R-4 Asparouhovo borehole). The lowermost $2 \mathrm{~m}$ of the unit are predominantly composed of detrital (mainly nummulitic) sandstones passing into sandy limestones in single cases. The chronostratigraphic range of the Beloslav Formation was determined as Ypresian based on nummulitids (AladjovaChrisčeva, 1991) and calcareous nannofossils (Stoykova, Vangelov, 1997). The lower boundary is a sharp lithologic contact with the Komarevo Formation. The upper boundary is a gradual transition to the Dikilitash Formation. The thickness of the formation varies from $2 \mathrm{~m}\left(\mathrm{C}^{\mathrm{I}}\right.$ Ravna Gora borehole) to $42 \mathrm{~m}$ (C-59 Zdravets borehole), but it is usually $5-10 \mathrm{~m}$ thick.

\section{The Dikilitash Formation (Gočev, 1933)}

The unit consists of alternation of pale-gray to gray-greenish fine- to middle-grained sands and fine-grained limy, quartz to quartz-glauconite sandstones (up to $1 \mathrm{~m}$ thick). Abundant nummulitic remains, forming lenses, were recorded at some levels. The chronostratigraphic range of the Dikilitash Formation was determined as Ypresian based on nummulitids (Aladjova-Khrischeva, 1984; Aladžova-Hrisčeva, 1990). The lower boundary is a gradual transition from the Beloslav Formation or an unconformity with the Komarevo Formation. The upper boundary is a sharp lithologic contact with the Aladan Formation or an unconformity with the Avren Formation. The thickness of the formation varies from $9 \mathrm{~m}$ (R-70 Bliznatsi borehole) to $128 \mathrm{~m}$ (C-47 Zvezditsa borehole).

\section{The Aladan Formation (Gočev, 1933)}

The formation consists of pale-gray to gray-greenish sandy limestones containing glauconite grains and sandy-glauconite lenses. A large amount of nummulitic remains was recorded. The chronostratigraphic range of the Aladan Formation was determined as Ypresian based on recovered nummulitic fauna (Aladjova-Khrischeva, 1984; Aladžova-Hrisčeva, 1990). The lower boundary is a sharp lithologic 
contact with the Dikilitash Formation or an unconformity with the Beloslav or Komarevo Formations. The upper boundary is a sharp contact with the Avren Formation. The thickness of the unit varies from $1 \mathrm{~m}$ (R-4 Asparouhovo, C-3 Asparouhovo, C-9 Asparouhovo, C-25 Zvezditsa, C-42 Zvezditsa, C-49 Konstantinovo, C-50 Konstantinovo boreholes) to $85 \mathrm{~m}$ (R-76 Ravna Gora borehole), but it is usually $5-10 \mathrm{~m}$.

\section{The Avren Formation (Gočev, 1933)}

This unit is characterized by variability in its lithological features. The main type is marl. It is palegrey to grey-greenish, thin-bedded, generally limy in the lower levels and clayey in the upper ones. Sandy and silty marls (containing mica flakes, pyrite and glauconite grains), marly limestones, and thin interbeds of sandstones are also characteristic for the lower levels in some cases. Rare remains of macroflora and squames of fishes were recorded in the upper levels in some sections. A distinct package of grey to dark-gray limy clays, containing squames of fishes, occupies predominantly the lower levels of the formation in the northern and central part of the Avren Step. Its thickness varies from $1 \mathrm{~m}$ (C-5 ${ }^{\mathrm{I}}$ Bliznatsi borehole) to $15 \mathrm{~m}$ (C-64 Zdravets and C-44 Konstantinovo boreholes), but there is a single borehole log (C-29 Priseltsi) revealing a thicker clayey package $(30 \mathrm{~m})$. A large amount of planktonic foraminiferal remains determining uppermost Ypresian-lowermost Priabonian age (reinterpretation of data given by Dacheva, 1962f; Kulev et al., 1965f; Shutskaya et al., 1972f6; as well as unpublished data by Juranov) was recorded. Both lower (with the Aladan Formation) and upper (with the Ruslar Formation) boundaries of the Avren Formation are sharp lithologic contacts. The thickness of the unit varies from $38 \mathrm{~m}$ (C-15 priseltsi borehole) to $428 \mathrm{~m}\left(\mathrm{C}-12^{\mathrm{I}}\right.$ Priseltsi borehole $)$.

\section{The Ruslar Formation (Zlatarski, 1927)}

The formation is composed predominantly of clays. They are gray to gray-greenish, thin-bedded, silty in the lower levels. These levels contain also sporadic interbeds of rhyolite tuffs. Limestone $(2 \mathrm{~m})$ and siltstone to sandstone packages $(2.5$ to $20 \mathrm{~m})$ at the base of the unit were recorded in some borehole

\footnotetext{
6 Shutskaya, E., A. Vaptsarova, M. Tanev, B. Goncharenko, D. Dencheva, A. Dianov, K. Jekova, V. Ignatova, M. Kehayova, G. Kulaksazov, T. Nikolov, A. Olferyev, A. Pozemova, I. Sapunov, Ch. Spasov, S. Stefanov, Y. Tenchov, E. Trifonova, D. Tronkov, P. Tsaneva, V. Tsankov, S. Yanev. 1972f. Report on Topic I. Subdivision and Correlation of Borehole Sections in North Bulgaria. Ministry of Energy, National Geological Fund, report III-247, 959 p. (in Russian).
}

sections in the northern part of the area. Several levels contain pyrite grains, charred plant remains, squames of fishes, and sponge spicules. The chronostratigraphic range of the Ruslar Formation is determined as Oligocene based on rare planktonic foraminiferal remains (Juranov, unpublished data). The lower boundary is a sharp lithologic contact with the Avren Formation. The upper boundary is an unconformity with the Neogene Galata Formation (introduced by Popov, Kojumdgieva, 1987). The thickness of the unit varies from $109 \mathrm{~m}$ (C-64 Zdravets borehole) to over $400 \mathrm{~m}$ (409 $\mathrm{m}$ in R-70 Bliznatsi borehole, $545 \mathrm{~m}$ in R-76 Ravna Gora borehole).

\section{Regional lithostratigraphic aspects}

Examples of the distinguished lithostratigraphic successions in different localities are shown in Figs 4 and 5 by illustration of 22 representative borehole sections. The spatial distribution and relationships of the lithostratigraphic units in the northern part of the studied area are visualized by drawing up of five geological cross-sections (Figs 6, 7), while the deep geological structure of the southern part is shown by the lithostratigraphic interpretation of the five migrated 2D seismic profiles (Figs 8, 9).

The lithobody tentatively referred herein to the Komarevo Formation shows variable lithological characteristics throughout the area of its distribution (this fact was also recorded in the Eastern Fore Balkan by Vangelov, Sinnyovsky, 2007), although they differ from these in the type area in central North Bulgaria (Datchev, 1975). The lower boundary of the unit was penetrated only in 12 boreholes, therefore it is not possible to record the entire spatial distribution and thickness varieties. Generally, the last one increases to the South.

The Beloslav and Dikilitash Formations show constant lithology throughout the area of their distribution. Characteristic for both units is that their color (pale-gray to gray-greenish) differs from the color, described in the type area (yellowish to lightbeige and white to gray respectively) as well as in Dobrogea (Valchev et al., 2018) and the Varna Plateau (Valchev et al., 2019). The Beloslav Formation demonstrates almost constant (with single exception) thickness (up to $15 \mathrm{~m}$ ), while the Dikilitash Formation shows great varieties. Generally, its thickness decreases to the South.

Previous investigations on the outcrops near the town of Beloslav have revealed the presence of two lithobodies amongst the sands and sandstones of the Beloslav Formation: shelly marker (Gočev, 1933; Belmoustakov, 1962; Aladjova-Khrischeva, 1984; Aladžova-Hrisčeva, 1990; Cheshitev et al., 

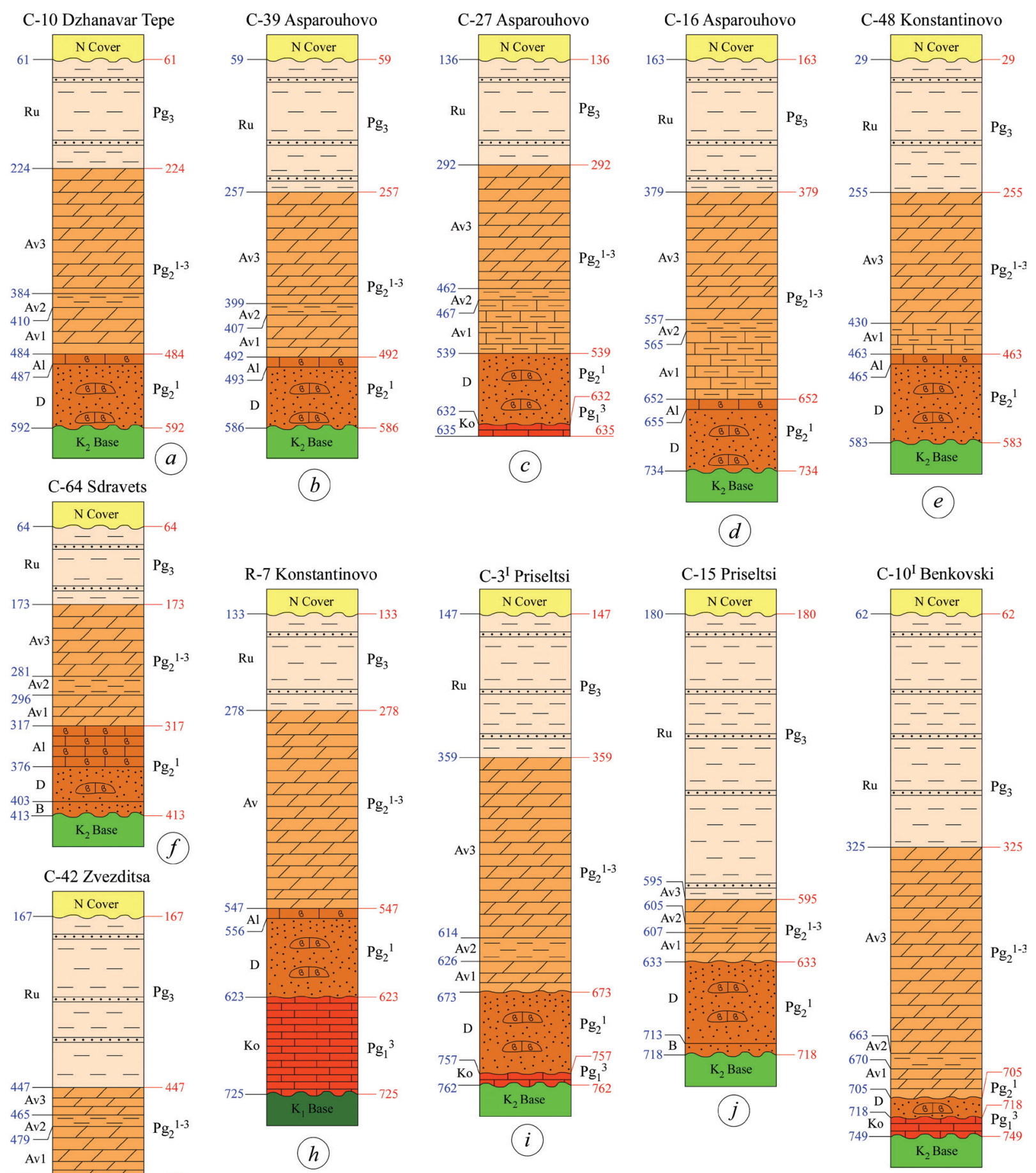

(h)

(k)

Fig. 4. Lithological logs of selected borehole sections from the northern part of the study area as examples for the recorded lithostratigraphic successions

$a-d$, Asparouhovo area; $e, h$, Konstantinovo area; $f$, Zdravets area; $g$, Zvezditsa area; $i-k$, Priseltsi area

Abbreviations: Ko, Komarevo Fm.; B, Beloslav Fm.; D, Dikilitash Fm.; Al, Aladan Fm.; Av, Avren Fm. (Av1, lower marly, limy marl or marly limestone package, Av2, clayey package, Av3, marly or upper marly package, Av, marls with or without sandstone interbeds; see also Fig. 10); Ru, Ruslar Fm.

Фиг. 4. Литоложки колонки на избрани сондажни разрези от северната част на изучения район като примери за документираните литостратиграфски последователности

$a-d$ - площ Аспарухово; $e, h$ - площ Константиново; $f$ - площ Здравец; $g$ - площ Звездица; $i-k-$ площ Приселци

Съкращения: Ко - Комаревска свита; В - Белославска свита; D - Дикилиташка свита; Al - Аладънска свита; Av - Aвренска свита (Av1 - долна мергелна, варовиково-мергелна или мергелно-варовикова пачка, Av2 - глинеста пачка, Av3 - мергелна или горна мергелна пачка, Av - мергели с или без пясъчникови прослойки; виж също фиг. 10); $\mathrm{Ru}-$ Русларска свита 


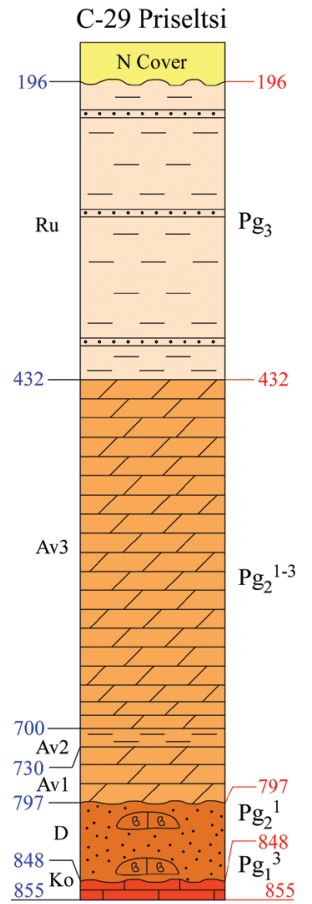

(a)

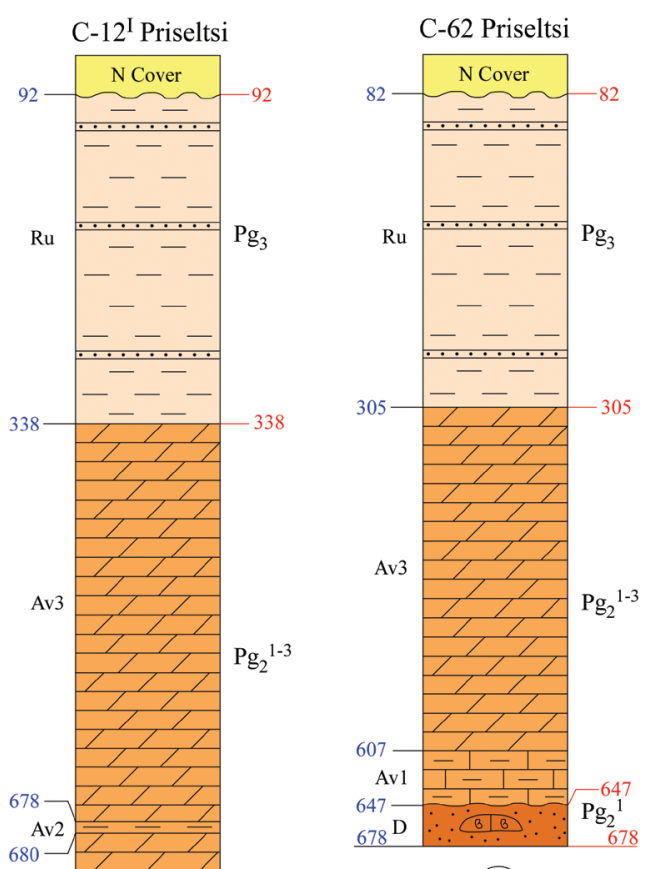

(c)

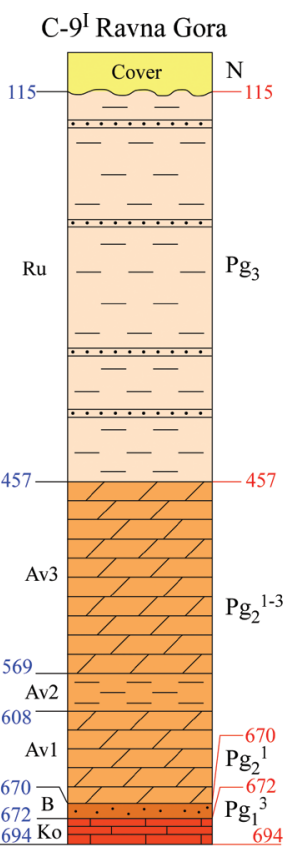

(d)

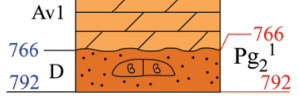

(b)
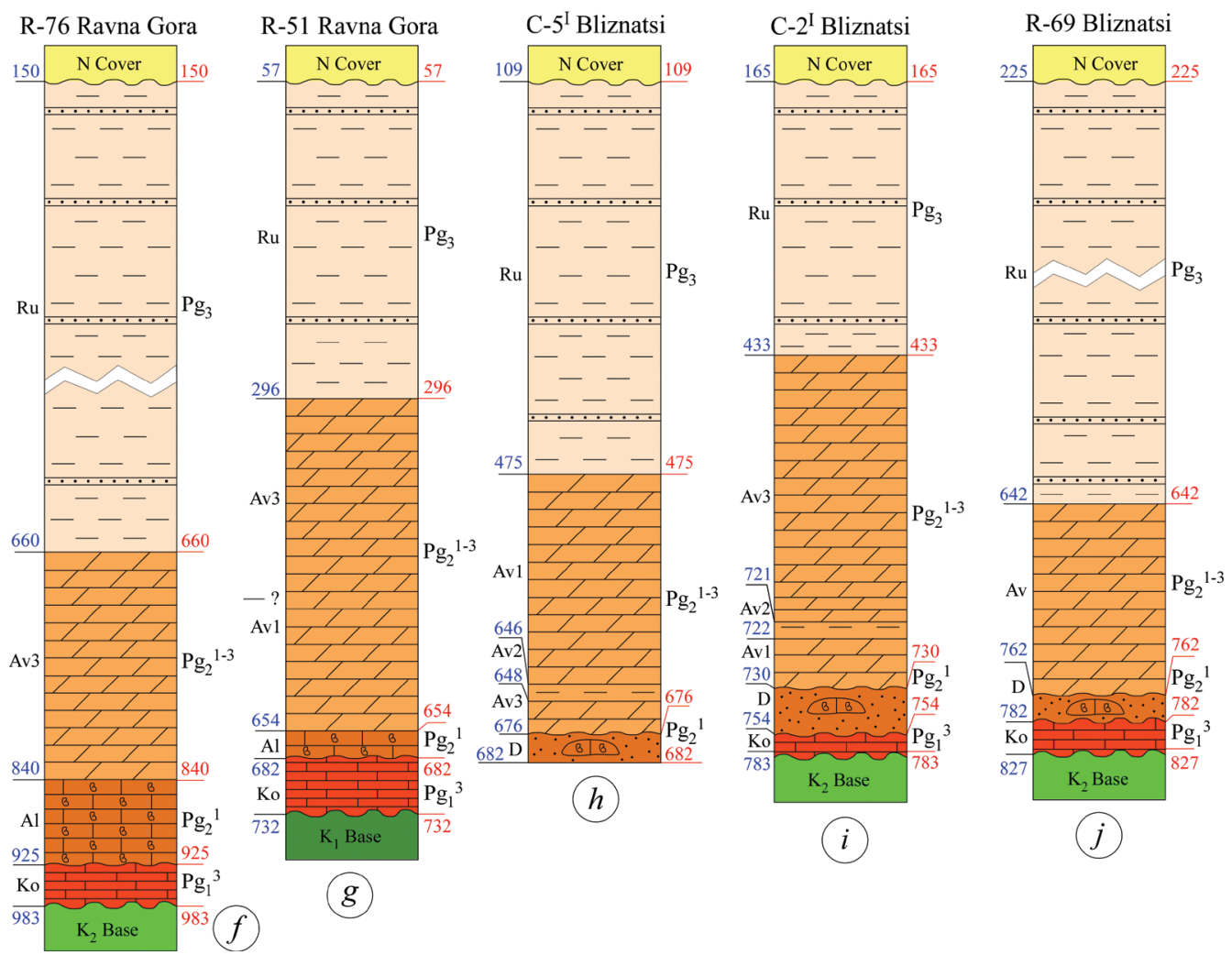

R-70 Bliznatsi

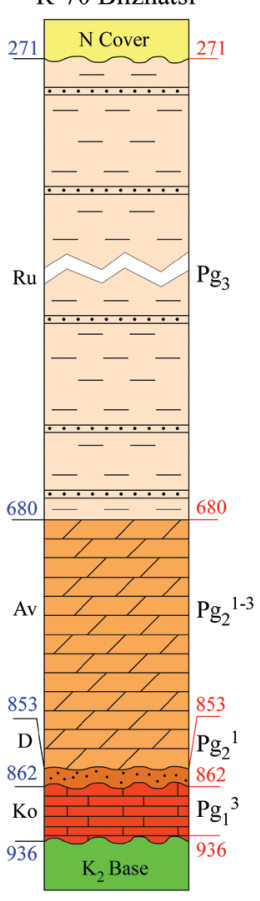

(k)

Fig. 5. Lithological logs of selected borehole sections from the southern part of the studied area as examples for the recorded lithostratigraphic successions

$a-c$, Priseltsi area; $d-g$, Ravna Gora area; $h-k$, Bliznatsi area

Abbreviations are the same as in Fig. 4

Фиг. 5. Литоложки колонки на избрани сондажни разрези от южната част на изучения район като примери за документираните литостратиграфски последователности

$a-c-$ площ Приселци; $d-g-$ Равногорска площ; $h-k-$ Близнашка площ

Съкращенията са както на фиг. 4 


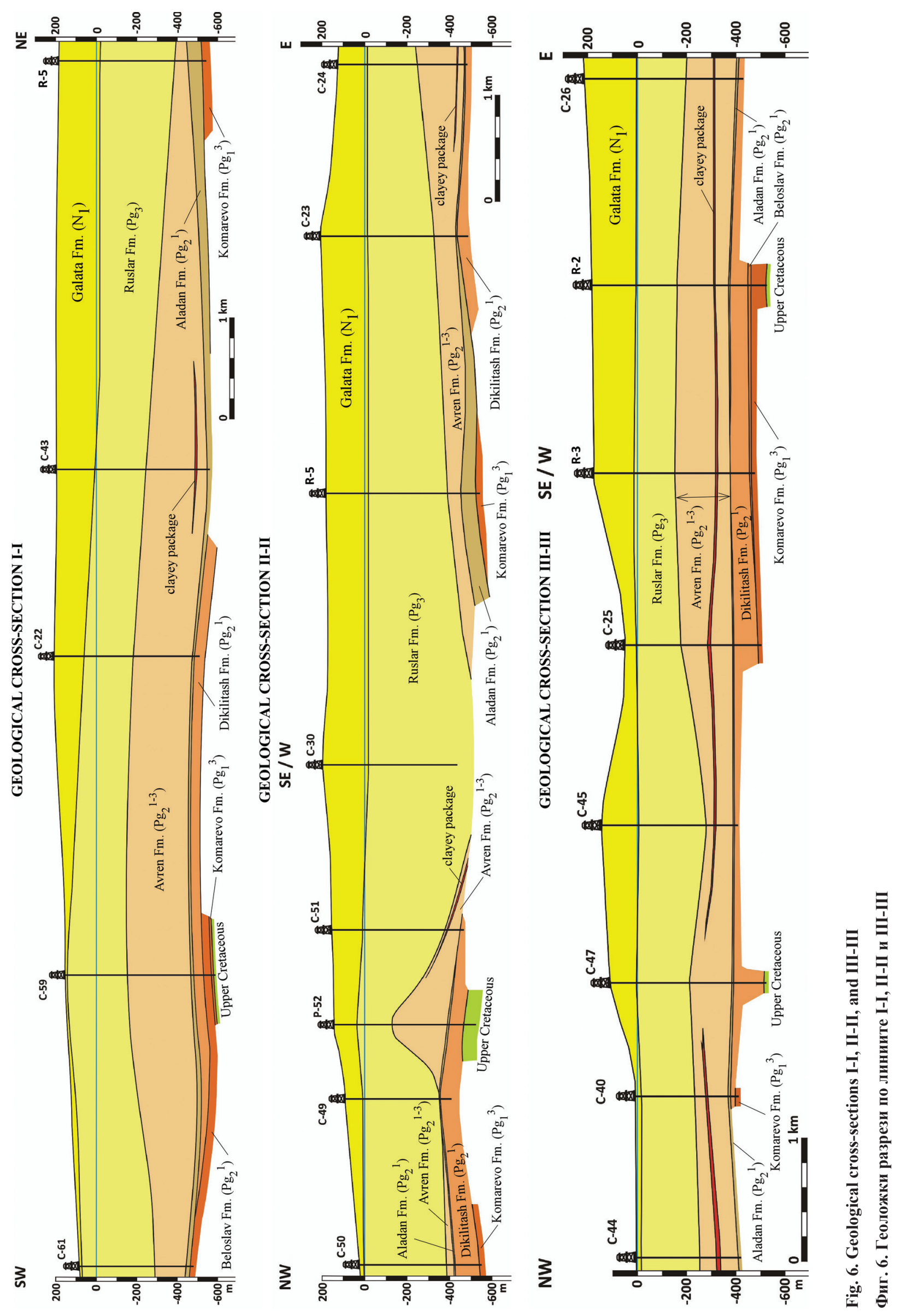



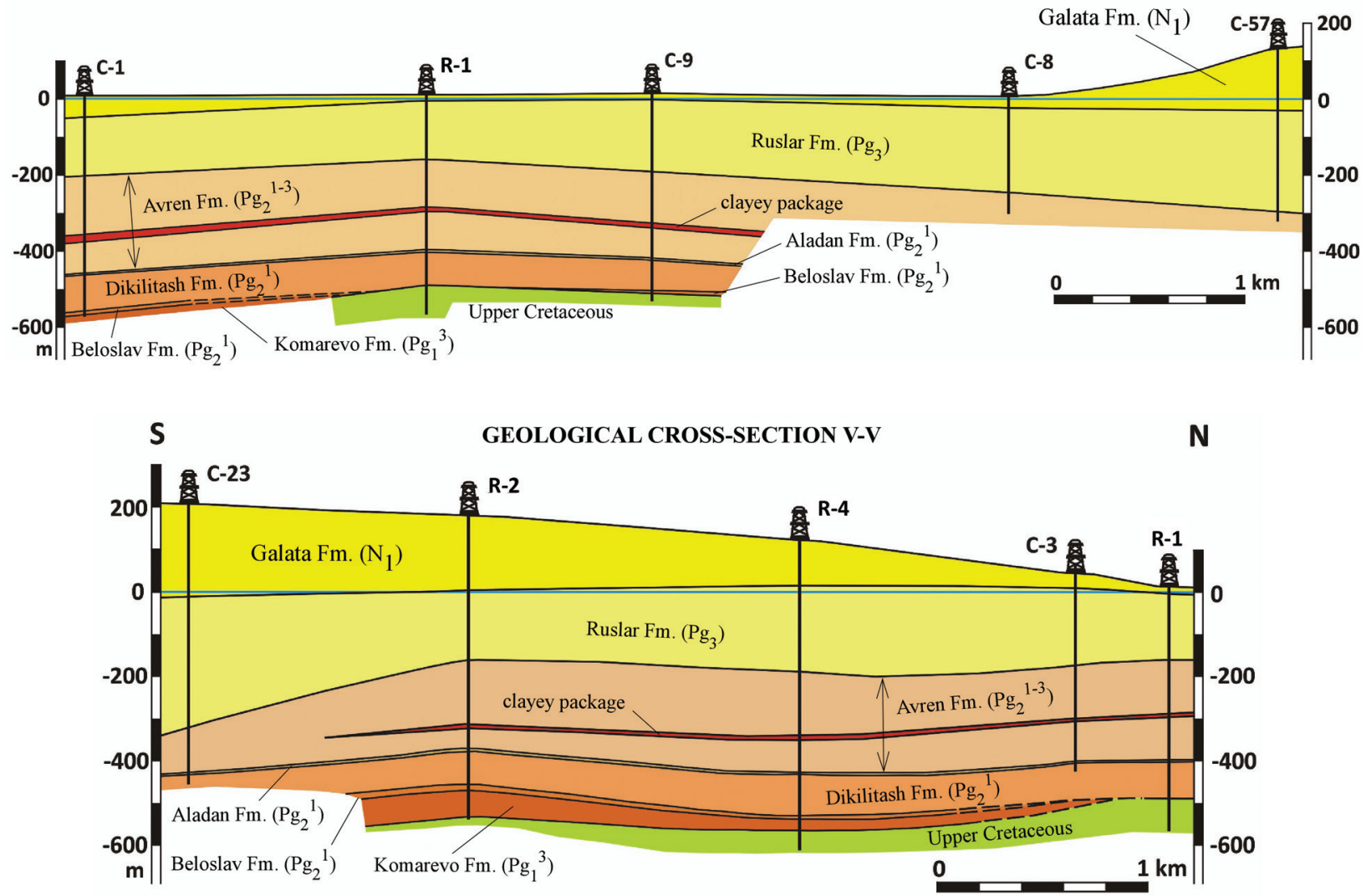

Fig. 7. Geological cross-sections IV-IV and V-V

Фиг. 7. Геоложки разрези по линиите IV-IV и V-V

1994) and a marly package (package 6 of AladjovaKhrischeva, 1984) decribed as Krivnya Member of the Beloslav Formation (Aladžova-Hrisčeva, 1990; see also Juranov, 1993) or Krivnya Formation west of Provadiya River (Cheshitev et al., 1994). Our study did not establish these lithobodies and therefore we assume that they are distributed only along the western edge of the Avren Plateau.

The Aladan Formation demonstrates constant lithologic record throughout the whole studied area, while its thickness is greatly variable. Therefore we couldn't record any trend (for example in Ravna Gora area the thickness varies from $2 \mathrm{~m}$ in R-6 borehole to $85 \mathrm{~m}$ in R-76 borehole; in Zvezditsa area the variations range from $1 \mathrm{~m}$ in C-45 borehole to $75 \mathrm{~m}$ in R-5 borehole).

The thickness of the Beloslav, Dikilitash and Aladan Formations, as well as the resolution of the seismic profiles do not allow their visualization as separate lithobodies and therefore, they are shown together (Figs 8, 9).

The Avren Formation was established in all borehole sections with exception of C-49 Konstantinovo, and it shows the most diverse record. We recognized seven cases of lithologic successions (Fig. 10):

1) Some of the sections in the northern part of the Avren Step, as well as single ones in the central and southern part are composed of two distinct levels separated by the clayey package - limy marl package, composed of sandy to limy marls, and marly package, including silty marls; 2) Several logs in different parts of the area are divided into lower and upper marly package, also separated by the clayey package. The marls beneath and above the clays demonstrate similar lithologic features - they are silty and contain mica flakes, sporadic glauconite grains and squames of fishes; 3) Four borehole logs in Zvezditsa area are composed entirely of silty marls with thin sandy interbeds in the lower levels. No clayey package was recorded here; 4) Monotonous marly succession was established in seven logs in the central north and the south-easternmost parts of the area. The marls contain mica flakes and rare pyrite grains; 5) A single $\log$ (R-76 Ravna Gora borehole) is entirely composed of sandy marls; 6) Five sections are divided into lower and upper marly packages (separated 

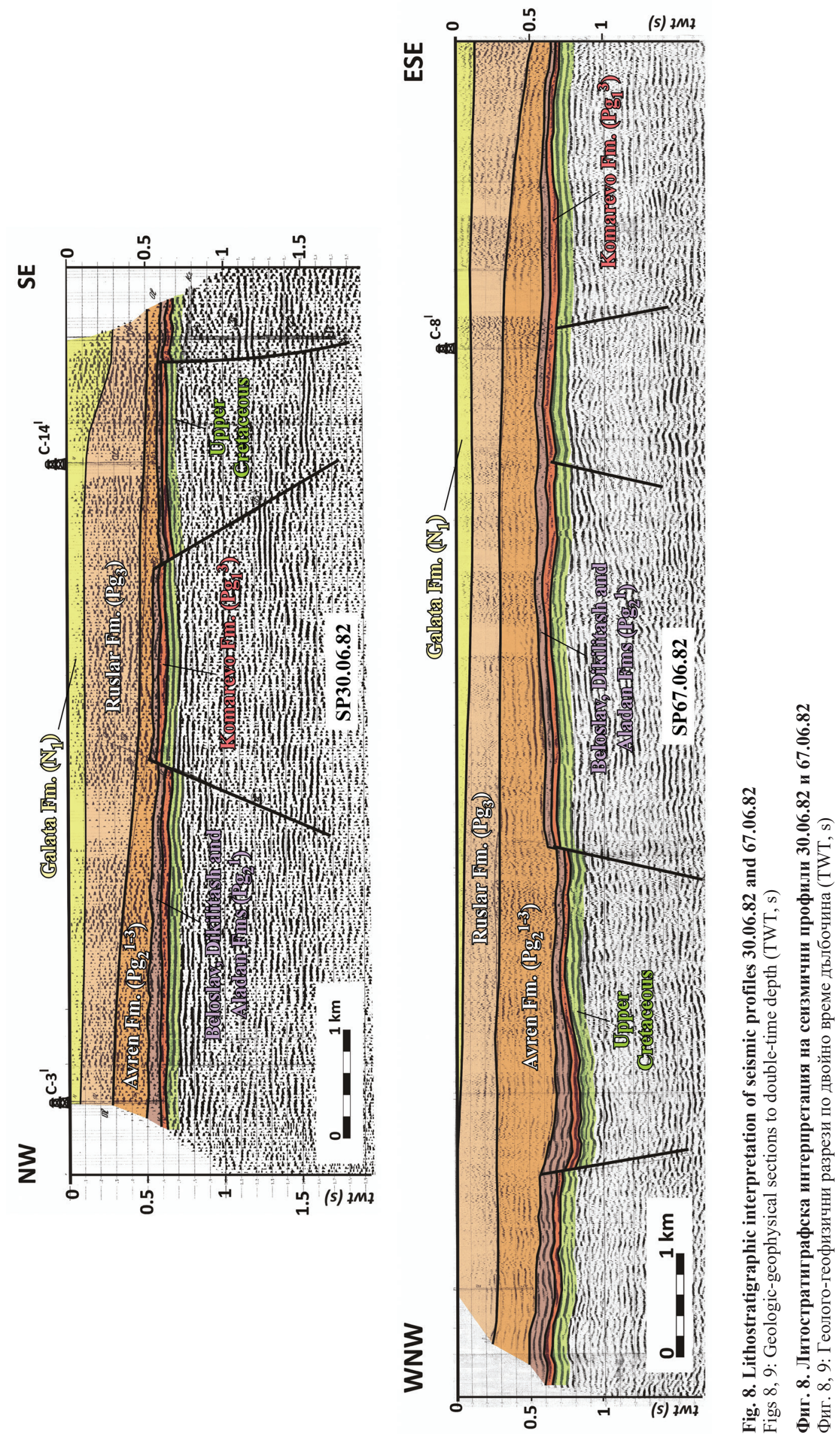

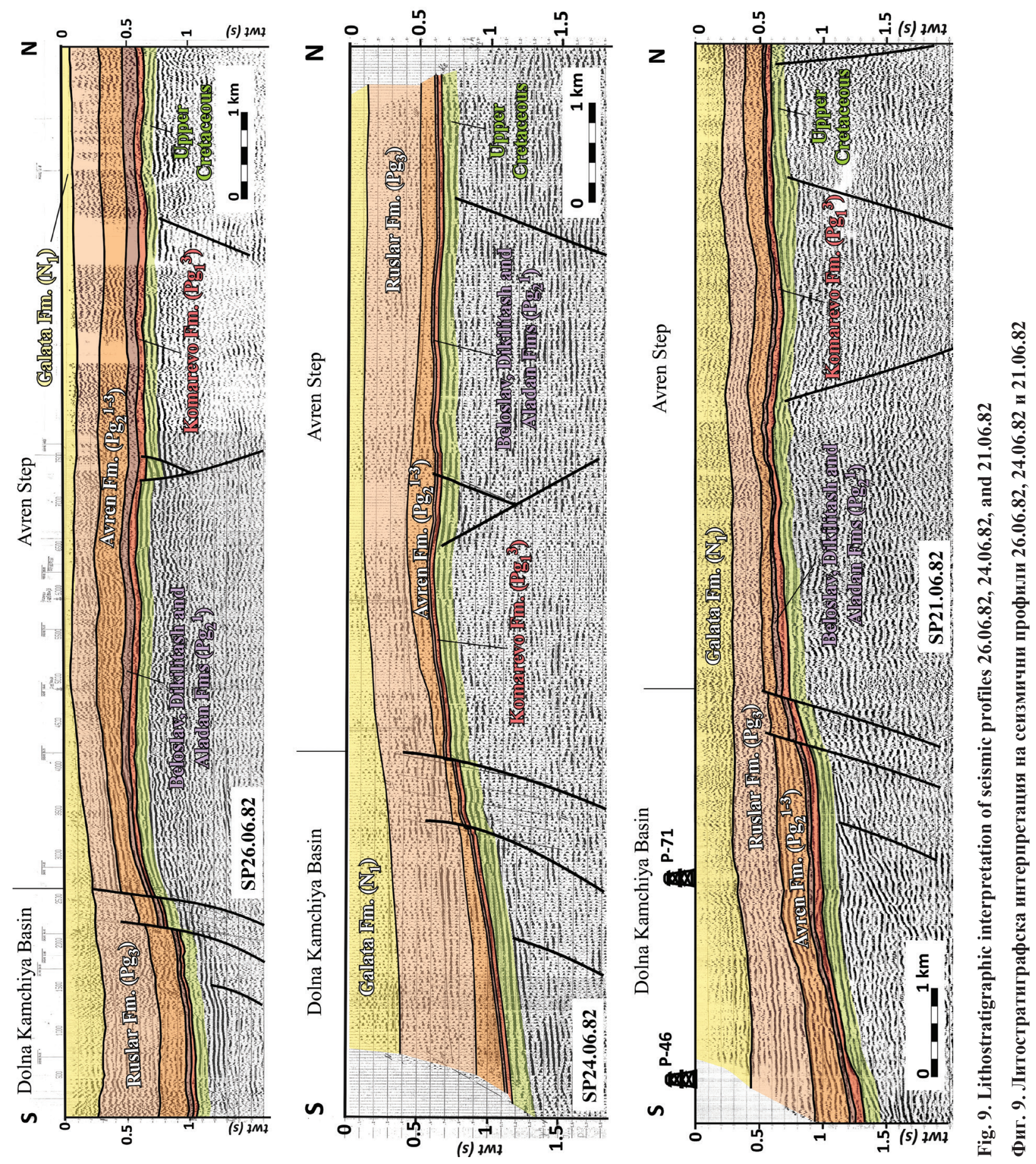


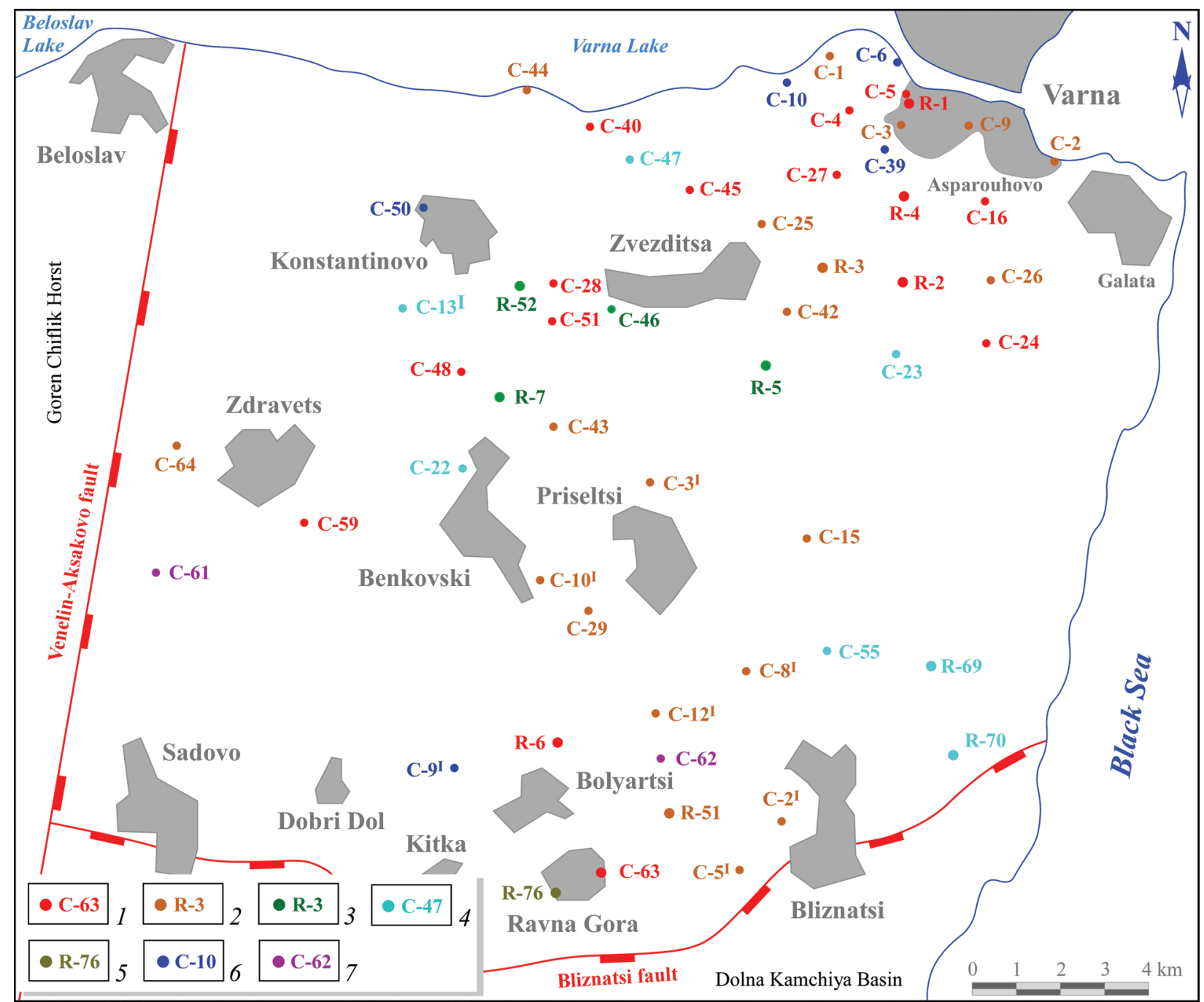

Fig. 10. Spatial lithological feature's variations of the Avren Formation

1, limy marl and marly packages; 2, lower and upper marly packages; 3, marl succession with sandstones in the lower levels; 4 , marl succession; 5 , sandy marls; 6 , lower marly package with sandstones and rare limestones and upper marly package; 7, marly limestone and marly packages. Only boreholes with penetrated lower formation's boundary are shown in the figure.

Фиг. 10. Пространствени вариации в литоложките особености на Авренската свита

1 - пачка от варовити мергели и мергелна пачка; 2 - долна и горна мергелна пачка; 3 - мергелен разрез с пясъчници в основата; 4 - мергелен разрез; 5 - песъчливи мергели; 6 - долна мергелна пачка с пясъчници и по-рядко варовици и горна мергелна пачка; 7 - мергелно-варовикова и мергелна пачка. На фигурата са посочени само сондажи, в които е премината и долната граница на единицата.

by the clayey package). Characteristic feature of the lower one is the presence of sandstone and rare limestone interbeds; 7) Two logs in the southern part of the Avren Step include two distinct levels - marly limestone package in the lower levels, composed of clayey or sandy limestones with interbeds of sandstones, covered by marly package, containing silty marls with mica flakes. No clayey package was recorded here.

It could be seen that there is no trend in the spatial distribution of these lithologic varieties. For example, we recorded six cases of lithologic successions in southernmost part (Ravna Gora and Bliznatsi areas) and four ones in the north-easternmost part of the Avren Step (Asparouhovo area).

The Ruslar Formation is also widespread in the entire studied area. Compared to Dobrogea and the Varna Plateau its lithologic record in the Avren Step is comparatively homogenous. No marly package and manganese ores were established. The lower levels of the unit are more silty than the upper ones, but there are no evidences for dividing of two packages. As a whole the thickness of the Ruslar Formation increases to the South. 


\section{Conclusions}

The lithostratigraphic investigation of the Paleogene in the Avren Step south of Varna and Beloslav Lakes by means of lithostratigraphic interpretation of borehole logs and seismic profiles confirmed the wide subsurface distribution of the Paleogene sedimentary successions across the whole investigated area. The presence of six formal units, which have been introduced and described previously, was proved. The numerous borehole data allowed elucidation of the regional aspects (lithology, thickness, spatial distribution and relationships) of the lithostratigraphic units. Four of them (the Beloslav, Dikilitash, Aladan and Ruslar Formations) demonstrate almost constant lithology throughout the whole studied area with some variations in their thickness. The Komarevo Formation, and especially the Avren Formation, show considerable lithologic and thickness variability. Compared to other parts of the Moesian Platform in Northeast Bulgaria (Dobrogea and the Varna Plateau) the internal structure of the Avren and Ruslar Formations does not allow their subdivision into three individual packages.

The collected database gives a good opportunity for clarifying the Paleogene part of the deep geologic structure of this sector of the Moesian Platform, and also for further palaeogeographic studies.

Acknowledgements: The authors thank Dr. Sava Juranov, Depatrment of Geology, Palaeontology and Fossil Fuels, Sofia University "St. Kliment Ohridski" for the kindly provided foraminiferal data as well as for his useful suggestions.

\section{References}

Aladjova-Khrischeva, K. 1984. Stratigraphie des dépôts éocènes aux environs du village Beloslav, département de Varna. - Rev. Bulg. Geol. Soc., 45, 1, 33-44 (in Bulgarian with French abstract).

Aladžova-Hrisčeva, K. 1990. Stratigraphy of the Lower Eocene sediments in part of the plateaus in Northeast Bulgaria. Rev. Bulg. Geol. Soc., 51, 1, 21-31 (in Bulgarian with English abstract).

Aladjova-Chrisčeva, K. 1991. Stratigraphic subdivision and correlation of Paleogenic deposits in Northeast Bulgaria. - Geologica Balc., 21, 2, 12-38 (in Russian with English abstract).

Belmoustakov, E. 1962. Stratigraphie du Paléogène Inférieur des plateaux de la Bulgarie Septentrionale. - Bull. Geol. Inst., 10, 89-118 (in Bulgarian with French abstract).

Bokov, P., G. Georgiev, I. Monahov, A. Atanasov, S. Jelev, Ch. Dachev, D. Yordanova, M. Vavilova, M. Nikolova, R. Ognyanov. 1987. Tectonic zoning. - In: Bokov, P., Ch. Chemberski (Eds). Geological Premise for the Oil-gas Bearing of the Northeast Bulgaria. Sofia, Tehnika, 109119 (in Bulgarian).

Cheshitev, G., V. Milanova, N. Popov, E. Kojumdgieva. 1991. Geological Map of Bulgaria at a Scale 1:100 000. Varna and Resort Zlatni Pjasăci Map Sheets. Committee of Geology and Mineral Resources, Department of Geophysical Prospecting and Geological Mapping.

Cheshitev, G., V. Milanova, N. Popov, E. Kojumdgieva. 1994. Explanatory Note to the Geological Map of Bulgaria on Scale 1:100 000. Varna and Zlatni Pyassatsi Map Sheets. Committee of Geology and Mineral Resourses, Geology and Geophysics Ltd., Sofia, Avers, 75 p. (in Bulgarian with English abstract).

Dabovski, H., I. Zagorchev. 2009. Alpine tectonic subdivision of Bulgaria. - In: Zagorchev, I., H. Dabovski, T. Nikolov (Eds), Geology of Bulgaria. Part II, Mesozoic Geology. "Prof. Marin Drinov" Publishing House, Sofia, 30-37 (in Bulgarian with English abstract).

Datchev, D. 1975. Stratigraphie des dépôts Paléocènes dans la région de Pleven. - Rev. Bulg. Geol. Soc., 36, 1, 37-48 (in Bulgarian with French abstract).
Georgiev, G. 2012. Geology and hydrocarbon systems in the Western Black Sea. - Turkish Journal of Earth Sciences, 21, 723-754.

Gočev, P. 1933. Paläontologische und stratigraphische Untersuchungen über das Eocän von Varna. - Rev. Bulg. Geol. Soc., 5, 1, 1-82 (in Bulgarian with German abstract).

Juranov, S. 1993. Krivnya Marl Member of the Beloslav Formation. - In: Tenchov, Y. (Ed.). Glossary of the Formal Lithostratigraphic Units in Bulgaria (1882-1992). Bulgarian Academy of Sciences Publishing House, Sofia, p. 178 (in Bulgarian).

Popov, N., E. Kojumdgieva. 1987. The Miocene in Northeastern Bulgaria (lithostratigraphic subdivision and geological evolution). - Rev. Bulg. Geol. Soc., 48, 3, 15-33 (in Bulgarian with English abstract).

Stoykova, K., D. Vangelov. 1997. Nannofossil stratigraphy of the Lower Paleogene in Varna area (North-East Bulgaria). - Rev. Bulg. Geol. Soc., 58, 3, 179-187 (in Bulgarian with English abstract).

Valchev, B., D. Sachkov, S. Juranov. 2018. 3D lithostratigraphic model of the Paleogene of the onshore part of the Moesian Platform (Northeast Bulgaria). - Geologica Balc., 47, 1, 23-36.

Valchev, B., D. Sachkov, S. Juranov. 2019. Paleogene lithostratigraphy in the Varna Plateau (Northeastern Bulgaria): a new view based on 3D modeling. - Rev. Bulg. Geol. Soc., 80, 1, 41-53.

Vangelov, D., D. Sinnyovsky. 2007. Stratigraphy of the Upper Cretaceous and Paleogene in a part of the Eastern Fore Balkan between the rivers Luda Kamchia and Armera. - Ann. Univ. de Sofia, Fac. géol. et géogr., 99, 1-géol., 31-51 (in Bulgarian with English abstract).

Yolkichev, N. 1986. Lithostratigraphic units related to the Upper Cretaceous in the west and central Fore-Balkan. - Rev. Bulg. Geol. Soc., 47, 3, 49-61 (in Bulgarian with English abstract).

Zlatarski, G. 1927. La Géologie de la Bulgarie. Sofia, Publ. House "Hudozhnik", Univ. Library, 65, 268 p. (in Bulgarian with French abstract).

Постъпила на 27.05.2020 г., приета за печат на 11.06.2020 г. Отговорен редактор Димитьр Синьовски 